\title{
Rival ministries collaborate on new research centres
}

Tokyo

From the end of this month, Japanese industry will be able to turn to a new Centre for Enhancing Research in Fundamental Technologies for help in carrying out basic research. Surprisingly, the new centre is to be run jointly by two ministries noted for their rivalry: the Ministry of International Trade and Industry (MITI) and the Ministry of Posts and Telecommunications (MPT).

Originally, the idea of a centre for basic research was dreamt up by MITI and finance requested in the 1985 budget. But at almost the same time. MPT began to demand that some of the money from the privatization of the state telecommunications monopoly, Nippon Telegraph and Telephone, which had been controlled by the ministry, should be used to finance a whole series of new telecommunication research centres. Although the initial demands of MPT were clearly excessive and seemed mainly inspired by a desire to dominate telecommunications research the government decided that MPT should at least share a new centre for research with MITI.

That decision came as something as a surprise, for MITI and MPT have been wrestling for some time to try to gain ministerial responsibility for data networks. MITI claims that as networks are just "linked computers", they fall into its traditional sphere of responsibility for computers; MPT, on the other hand, sees data links as being not much different from telephone lines and thus clearly its responsibility.

Interministerial struggles of this kind are quite common in Japan and make something of a nonsense of the Western image of a unified "Japan Inc.". Whatever their differences, anyway, in this case the two ministries now share responsibility for the new centre. It is not actually a research facility but an administrative body intended to help private industry to carry out basic research.

First, the centre will ensure that access to government research facilities is given to private industry at low cost. The idea is that the centre will act as a go-between so that better cooperation can be achieved between government, industry and the universities; lack of effective cooperation has long been one of Japan's weak points, despite Western myths to the contrary. The 16 research laboratories of MPT and MITI, including such giants as the Electrotechnical Laboratory, are particularly likely to be involved in such schemes.

Second, the centre will make direct lowinterest loans to companies launching joint fundamental research projects. In the event that the research does not succeed, the interest on the loan will not have to be repaid at all.

Where the research cannot be expected to produce any benefits in the near future, financial help will be given to set up new joint companies.

Third, the centre will take over the administration of the "Japan trust". This is a new charitable foundation set up to provide funds for foreigners to come and do research in Japan. Its capital has been provided by large industrial companies and it was founded partly to avert criticism that Japan sends many researchers to learn advanced techniques in the United States but offers very few opportunities to foreigners in return. Researchers to be invited under the scheme will be selected by the centre and responsibility taken for negotiation over rights to patents stemming from such international research.

Industry's recent spending spree on new basic research laboratories (see Nature 311, 404; 1984) shows that enthusiasm for basic research exists. The Y4,000 million (US\$17 million) available to the centre for this year's costs should certainly help to make the centre's services popular. But the traffic is not all one way; increased links with industry will also help to ease government research institutes' worries that they could be left behind by the increasingly vigorous laboratories attached to large companies.

Alun Anderson

\section{Eureka}

\section{West Germany commits itself}

BONN expects to have "no problem in financing" the French-inspired Eureka project for European collaboration in the development and production of new high technology products, a West German research ministry spokesman said on Monday. The provision of DM 100 million ( $£ 25$ million) by the research ministry next year is "definite", and the money will be spent on feasibility studies and project planning, while another DM 1,000 million ( $£ 250$ million) in grants to industrial participants in Eureka over the next five years is "almost decided".

These developments have been greeted with delight by the French government, which so far has been alone in making a clear financial allocation to Eureka. Before the summer, President François Mitterrand said France would commit FF 1,000 million ( $£ 90$ million) to Eureka projects in 1986 . Britain, by contrast, has hinted that no new government money will be found for the scheme, and has spearheaded attempts to raise interest among European banks and financial institutions.

But Bonn's interest is not free from strings. The West German ministry says that industry should provide the "bulk" of the funds (on top of the government's DM 1,100 million) that may be needed to develop products based on the Eureka technology, from robot tractors to supercomputers. And that "bulk" may be very large.

The inspiration for Eureka was the potential industrial spin-off from the United States Strategic Defense Initiative (SDI), on which $\$ 26,000$ million ( $£ 20,000$ million) is expected to be spent over the first five years, and Europe seems bound to make a comparable investment if there is to be a comparable effect. The publicly announced European commitments to
Eureka, however, amount to hardly 2 per cent of this sum.

Nevertheless, the West German commitment is symbolic and crucial, both for the "special relationship" between France and Germany and for Eureka. Relationships have been eroding badly in recent months, notably in Chancellor $\mathrm{Hel}$ mut Kohl's commitment to SDI and President Mitterrand's rejection of it. But, meanwhile, German negotiators in Washington are said to have become somewhat disenchanted with the US position, and, in particular, concerned that technology developed under the SDI umbrella with European help might be held under such strict export controls by the United States that its application in ordinary commerce might prove impossible. Hence the German position is felt to be shifting from an initial enthusiasm for SDI towards greater interest in the commercially-oriented Eureka.

On Eureka, apart from financial questions, they say in Bonn that "we still need to know what the Eureka project will be", and there is detectable concern that despite the continuing work of a 15-nation (plus the European Commission) expert group, there is no certain agreement on exactly what Eureka will do.

In France, there has been interest in supercomputers, in the use of lasers for surface treatments, the applications of a small intense electron synchrotron (also of interest to Italy, which seeks to place such a device in Trieste, as compensation for losing the European Synchrotron Radiation Facility to Grenoble), robotics and genetic engineering of drugs; Germany is also interested in environmental technologies. And with such a wide variety of issues available, it is still an open question whether anything concrete can be decided.
Robert Walgate 